\title{
Analysis of The Self-Confidence Level of Grade 4 Students at SD N 2 Brecong in Entrepreneurship Learning
}

\section{Arief Muhamad Fachrur Rozi, Siti Fatimah}

Universitas Sebelas Maret

ariefmuhamad14@gmail.com

\section{Article History}

accepted 24/09/2019 approved 01/10/2019 published 01/12/2019

\begin{abstract}
Self confidence is one of the factors that influences learning success. This study aims to analays the level of self-confidence of students in grade 4 at SD N 2 Brecong on entrepreneurial learning. This research was conducted at SD N 2 Brecong class 4 in the 2019/2020 school year. The design of this research is simple descriptive. Data collection techniques using observation and questionnaires with a population of 35 students. Data analysis was performed using descriptive techniques. Based on the results of the study it can be concluded that the confidence of grade 4 students at SD N 2 Brecong is good in their confidence. Entrepreneurial learning becomes a container in developing student learning confidence. The fourth grade students' self confidence developed at SD N 2 Brecong is supported by being independent, active in learning, discipline and responsibility.
\end{abstract}

Keywords: Confidence, Entrepreneurship Learning

\section{Abstrak}

Kepercayaan diri menjadi salah satu faktor yang mempengaruhi keberhasilan belajar. Penelitian ini bertujuan untuk menganalisis tingkat kepercayaan diri siswa kelas 4 SD N 2 Brecong pada pembelajaran kewirausahaan. Penelitian ini dilaksanakan di SD N 2 Brecong kelas 4 tahun ajaran 2019/2020. Desain penelitian ini berupa deskriptif sederhana. Teknik pengumpulan data menggunakan observasi dan angket dengan jumlah populasi 35 siswa. Analisis data dilakukan dengan teknik deskriptif. Berdasarkan hasil penelitian dapat disimpulkan bahwa kepercayaan diri siswa kelas 4 SD N 2 Brecong baik dalam kepercayaan dirinya. Pembelajaran kewirausahaan menjadi wadah dalam mengembangkan kepercayaan diri belajar siswa. Bentuk kepercayaan diri siswa kelas IV yang dikembangkan di SD N 2 Brecong didukung dengan diantaranya mandiri, aktif dalam belajar, disiplin dan tanggung jawab.

Kata kunci: Kepercayaan diri, Pembelajaran Kewirausahaan

Social, Humanities, and Education Studies (SHEs): Conference Series https://jurnal.uns.ac.id/shes 


\section{PENDAHULUAN}

Pendidikan merupakan hal penting yang diperlukan bagi setiap manusia untuk memperoleh pengetahuan, wawasan serta meningkatkan martabat dalam kehidupan. Sumber daya manusia dituntut untuk mampu menciptakan tata pendidikan yang dapat ikut menghasilkan sumber daya pemikir yang mampu membangun tatanan sosial dan ekonomi, sadar pengetahuan sebagaimana layaknya warga dunia pada abad 21 (Mukminan, 2014: 1). Tantangan ini ditekankan pada bidang pendidikan, sehingga dengan harapan dapat menciptakan sumber daya manusia yang mampu berpikir kritis, bersosialisasi, bekerja sama antar individu maupun kelompok dan paham akan perkembangan ilmu pengetahuan dan teknologi, sehingga dapat menghadapi segala tuntutan dan persaingan yang ada pada era globalisasi

Persaingan pada era globalisasi terdapat dalam berbagai bidang kehidupan, salah satu diantaranya adalah bidang pendidikan, khususnya pendidikan kewirausahaan. Manusia dihadapkan pada tuntutan akan pentingnya sumber daya manusia yang berkualitas serta mampu berkompetensi. Sumber daya manusia yang berkualitas, yang dihasilkan oleh pendidikan yang berkualitas dapat menjadi kekuatan utama untuk mengatasi masalah-masalah yang dihadapi dalam pendidikan, sehingga melalui pendidikan kewirausahaan diharapkan dapat menciptakan sumber daya yang benar benar berkualitas serta mampu berkompetisi.

Menurut Rachmadyanti (2016), Pendidikan kewirausahaan adalah pendidikan yang menerapkan prinsip- prinsip dan metodologi kearah pembentukan kecakapan hidup (life skill) pada siswa melalui kurikulum yang dikembangkan di sekolah. Dengan pendidikan kewirausahaan ini diharapkan siswa mempunyai sikap percaya diri yang baik yang ditanamkan sedini mungkin. Kualitas belajar siswa tidak hanya diukur dari hasil belajar berupa angka angka yang diperoleh setelah mengikuti setiap pembelajaran. Pembelajaran juga dapat memengaruhi pembentukan kualitas belajar serta kemampuan belajar beradaptasi dengan lingkungan. Kualiatas belajar juga diukur dari proses siswa mengikuti pembelajaran dan dampak pengiring dari proses tersebut. Salah satu dampak pengiring adalah adanya rasa percaya diri yang dimiliki siswa, yang membuat mereka mudah untuk berinteraksi dalam lingkungan belajarnya (Taufiq, 2011). Rasa percaya diri merupakan suatu keyakinan yang dimiliki seseorang bahwa dirinya mampu berperilaku seperti yang dibutuhkan, untuk memperoleh hasil seperti yang diharapkan. Seperti yang dikemukakan Hurlock (1999), "rasa percaya diri ditunjukkan oleh adanya suatu keyakinan bahwa seseorang dapat menyebabkan sesuatu terjadi sesuai dengan harapan-harapannya". Artinya, seseorang yang memiliki rasa percaya diri dapat mewujudkan harapannya dengan adanya suatu keyakinan pada diri seseorang.

Untuk dapat menciptakan sumber daya manusia yang mampu menghadapi era globalisasi, maka perlu adanya sikap kepercayaan diri siswa, yang harus ditanamkan sejak dini. Oleh karena itu, siswa perlu dipersiapkan melalui pendidikan, agar siswa dapat lebih memahami akan pentingnya kepercayaan diri. Namun kenyataannya, masih banyak pula ditemui guru yang menggunakan metode ceramah yang menyebabkan guru kurang interaktif pada saat proses pembelajaran berlangsung. Salah satu contoh metode pembelajaran yang dapat meningkatkan kemampuan kepercayaan diri siswa sehingga siswa tidak ragu-ragu dan bersikap pasif adalah dengan cara berdiskusi dalam kelompok yang akan melatih siswa untuk saling berinteraksi dengan teman kelompok

Dari informasi yang didapat, maka penulis memutuskan untuk melakukan penelitian dengan judul "Analisis Tingkat Kepercayaan Diri Siswa Kelas 4 SD N 2 Brecong pada Pembelajaran Kewirausahaan". 


\section{METODE}

Desain penelitian yang digunakan pada penelitian adalah desain deskriptif sederhana yang mengacu pada (Sudaryono, dkk., 2013: 9). Penelitian ini dilaksanakan tanggal 30 September 2019 di SD Negeri 2 Brecong yang beralamat di desa Brecong. Subjek dalam penelitian ini adalah siswa-siswi kelas IV SD Negeri 2 Brecong tahun ajaran 2019/2020, yang terdiri dari 35 siswa. Data penelitian ini berupa data kualitatif yaitu berupa tingkat kepercayaan diri siswa dilihat berdasarkan kriteria sangat baik, baik, cukup, kurang baik dan sangat kurang baik. Data penelitian diambil menggunakan 2 teknik pengumpulan data yaitu angket dan observasi.

Teknik analisis data yang digunakan dalam penelitian ini adalah analisis deskriptif dimana data dan informasi yang diperoleh dari lapangan dideskripsikan secara kualitatif. Pada penelitian ini untuk mengamati tingkat kepercayaan diri siswa menggunakan lembar observasi berupa angket. Lembar observasi ini digunakan peneliti untuk melihat tingkat kepercayaan diri yang terjadi pada saat dilaksanakan pembelajaran berkelompok dengan kriteria-kriteria mengenai tingkat kepercayaan diri.

$$
\text { Presentase }=\frac{\text { skor keseluruhan yang diperoleh }}{\text { Skor Maksimum }} \times 100 \%
$$

Hasil perhitungan dalam bentuk persentase kemudian diinterpretasikan dengan table kriteria tingkat kemampuan kerjasama siswa sebagai berikut.

\begin{tabular}{cc}
\hline \multicolumn{2}{c}{ SKALA PROSENTASE DATA } \\
\hline PROSENTASE & KETERANGAN \\
$0-29 \%$ & Sangat kurang baik \\
$30-59 \%$ & Kurang baik \\
$60-79 \%$ & Cukup \\
$80-89 \%$ & Baik \\
$90-100 \%$ & Sangat baik \\
\hline
\end{tabular}

HASIL DAN PEMBAHASAN

Berdasarkan hasil observasi terhadap tingkat kepercayaan diri siswa kelas IV SD N 2 Brecong dalam pembelajaran Kewirausahaan, maka diperoleh data sebagai berikut

1. Percaya pada kemampuan diri sendiri

a. Siswa yakin bisa membuat produk kerajinan.

Berdasarkan hasil observasi, ditemukan bahwa siswa mampu membuat produk kerajinan.

b. Saya yakin bisa menjelaskan cara membuat produk kerajinan

Berdasarkan hasil observasi, ditemukan bahwa siswa bisa menjelaskan cara membuat produk kerajinan dengan baik

c. Siswa berani mengungkapkan pendapat tanpa ragu-ragu.

Berdasarkan hasil observasi, siswa mampu mengungkapkan pendapat dengan yakin.

d. Siswa selalu yakin terhadap keputusan yang diambil

Berdasarkan hasil observasi, siswa mampu mengambil keputusan ketika tugas kelompok.

2. Bertindak mandiri

a. Siswa mampu menyelesaikan tugas secara mandiri dengan baik

Berdasarkan observasi, siswa mampu menyelesaikan tugas membuat produk dari manik-manik dengan mandiri bersama kelompoknya.

b. Siswa tidak selalu setuju dengan pendapat teman

Berdasarkan observasi, ditemukan siswa yang tidak sependapat dengan temanya.

c. Siswa menjawab pertanyaan yang ada sesuai pemikirannya. 
Berdasarkan observasi, siswa mampu menjawab pertanyaan guru sesuai pengetahuan yang dimiliki.

3. Memiliki rasa positif terhadap diri sendiri.

a. Siswa bisa membuat produk (manik-manik) yang menarik.

Berdasarkan observasi, setiap siswa mampu membuat kerajinan dari manikmanik dengan kreatif

b. Siswa yakin akan kemampuan diri sendiri

Berdasarkan observasi, siswa mampu membuat kerajinan sesuai kemampuanya.

c. Siswa menerima dan menyetujui jawaban yang telah didiskusikan

Berdasarkan observasi, siswa menerima kesimpulan atas jawaban teks yang dipelajari bersama.

d. Siswa memberikan dorongan dan motivasi kepada teman yang belum bisa membuat produk (manik-manik)

Berdasarkan observasi, siswa membantu teman yang gagal dalam membuat produk dari manik-manik.

4. Berani mengungkapkan pendapat.

a. Siswa selalu berpendapat dalam kegiatan kelompok

Berdasarkan observasi, sebagian besar siswa mampu mengungkapkan pendapatnya dengan baik.

b. Siswa malu untuk berpendapat dalam kelompok

Berdasarkan observasi, ditemukan sebagian kecil siswa yang malu untuk mengungkapkan pendapatnya.

c. Siswa menjelaskan kepada anggota kelompok yang belum jelas

Berdasarkan observasi, siswa membantu anggota kelompok yang belum jelas dalam pembuatan manik-manik.

d. Siswa melibatkan diri secara aktif ketika berdiskusi dengan kelompok Berdasarkan observasi, siswa aktif dalam pembuatan manik-manik.

HASIL PENELITIAN MENGGUNAKAN ANGKET

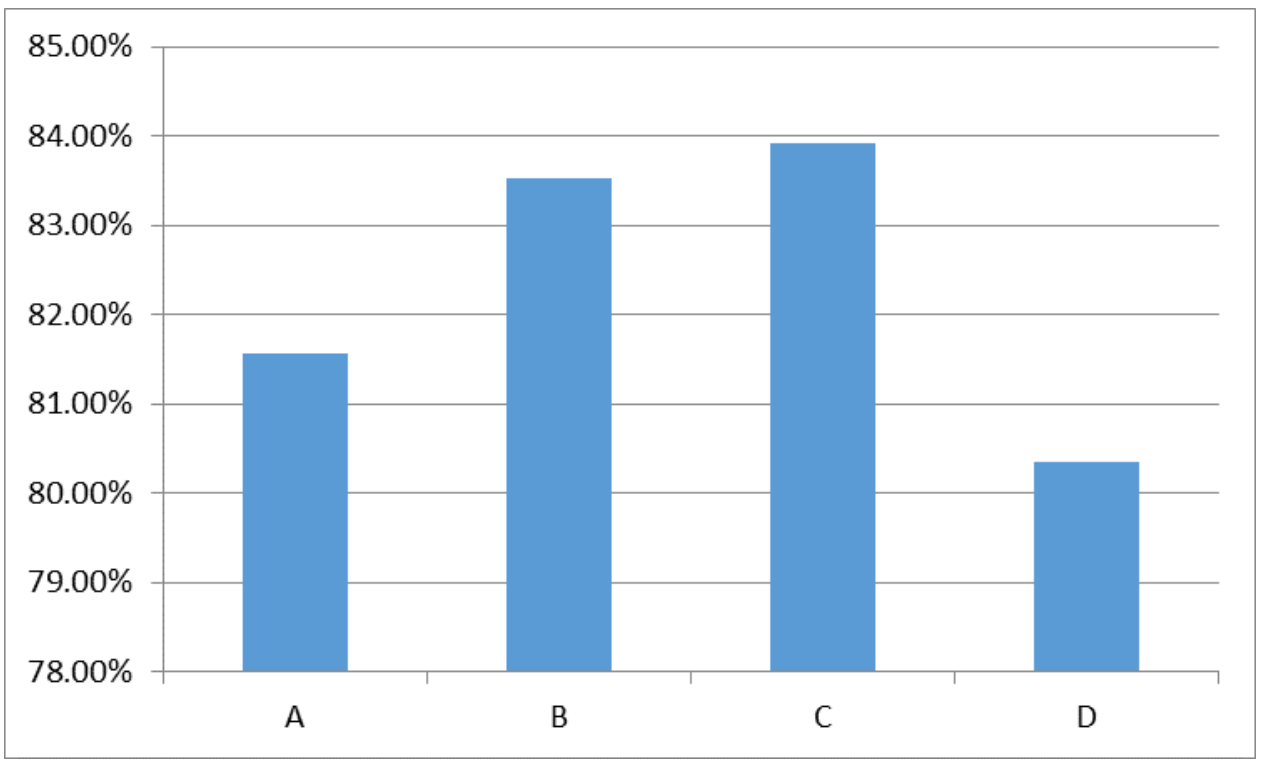

Gambar 1. Profil kemampuan Berpikir Kreatif dalam pembelajaran kewirausahaan kelas IV menggunakan angket. 
Ket: $\boldsymbol{A}=$ Percaya pada kemampuan diri sendiri ; $\boldsymbol{B}=$ Bertindak mandiri; $\boldsymbol{C}=$ memiliki rasa positif terhadap diri sendiri; $\boldsymbol{D}=$ Berani mengungkapkan pendapat.

Aspek yang menjadi titik tekan dari peneliti dan paling mencolok untuk diamati dalam pembelajaran kewirausahaan di SD N 2 Brecong, yaitu (1) percaya pada kemampuan diri sendiri, (2) bertindak mandiri, (3) memiliki rasa positif terhadap diri sendiri, (4) berani mengungkapkan pendapat. Berikut ini pembahasanya:

1. Percaya pada kemampuan diri sendiri

Berdasarkan data hasil observasi dan angket untuk mengetahui percaya pada kemampuan diri , menunjukan hasil 81,56 \% dimana hasil tersebut masuk kategori baik. Hal ini ditunjukan dengan siswa mampu membuat produk kerajinan dari manik-manik dengan idenya sendiri yang menghasilkan motif berbeda-beda tiap siswanya dalam kelompok tersebut. Selain itu siswa juga sudah percaya diri dalam menjual produk kepada siswa kelas lain di lingkungan sekolah. Dengan demikian hasil observasi dan angket sesuai dengan indikator percaya pada kemampuan diri sendiri.

2. Bertindak mandiri

Berdasarkan data hasil observasi dan angket untuk mengetahui siswa bertindak mandiri, menunjukan hasil $83,53 \%$ dimana hasil tersebut masuk kategori baik. Hal ini ditunjukan dengan sebagian besar siswa mampu mengerjakan tugas membuat kerajinan dari manik-manik tanpa bantuan guru. Ketika diberi pertanyaan oleh guru, siswa juga mampu menjawab pertanyaan sesuai dengan kemampuan dan pemahamannya. Dengan demikian hasil observasi dan angket sesuai dengan indikator kemampuan bertindak mandiri.

3. Memiliki rasa positif terhadap diri sendiri.

Berdasarkan data hasil observasi dan angket untuk mengetahui rasa positif terhadap diri sendiri, menunjukan hasil $83,92 \%$ dimana hasil tersebut masuk kategori baik. Hal ini ditunjukan dengan setiap siswa memiliki ide yang berbeda satu dengan yang lainnya dan mereka tidak mau meniru temannya dalam membuat produk kerajinan dari manik-manik. Dengan demikian hasil observasi dan angket sesuai dengan indikator memiliki rasa positif terhadap diri sendiri.

4. Berani mengungkapkan pendapat

Berdasarkan data hasil observasi untuk mengetahui keberanian mengungkapkan pendapat, menunjukan hasil $80,35 \%$ dimana hasil tersebut masuk kategori baik. Hal ini ditunjukan dengan ketika guru memberikan pertanyaan, sebagian siswa mengangkat jarinya untuk menjawab pertanyaan tersebut dan menjawab sesuai pendapat masing-masing. Selain itu, ketika dalam kegiatan kelompok membuat kerajinan dari manik-manik, ada siswa yang salah dalam proses pembuatanya, teman kelompoknya memberi saran cara yang benar merurut pemikiran dia. Dengan demikian hasil observasi dan angket sesuai dengan indikator kemampuan berani mengungkapkan pendapat.

\section{SIMPULAN}

Berdasarkan hasil penelitian dan pembahasan, maka dapat disimpulkan bahwa tingkat kepercayaan diri siswa pada pembelajaran kewirausahaan di SD Negeri 2 Brecong memiliki kriteria baik dilihat dari beberapa aspek. Pada aspek percaya pada kemampuan diri sendiri memiliki kriteria baik, yaitu 81,56\%. Pada aspek bertindak mandiri memiliki kriteria baik, yaitu $83,53 \%$. Pada aspek memiliki rasa positif terhadap diri sendiri memiliki kriteria baik, yaitu $83,92 \%$. Sedangkan pada aspek berani mengungkapkan pendapat memiliki kriteria baik, yaitu $80,35 \%$. 
DAFTAR PUSTAKA

Hurlock, E.B. (1999). Psikologi Perkembangan Suatu Pendekatan Sepanjang Rentang Kehidupan. Cetakan Ke-5. Surabaya: PT. Gelora Aksara Pratama Erlangga.

Mukminan. (2014). Tantangan Pendidikan Di Abad 21. Yogyakarta: Universitas Negeri Yogyakarta: Diakses pada tanggal 24 September 2019

Rachmadyanti, Putri dan Vicky Dwi Wicaksono. (2016). Pendidikan Kewirausahaan Bagi Anak Usia Dasar. http://jurnal.fkip.uns.ac.id/indek.php/snip/article/view/8960/6521

Sudaryono, dkk. (2013). Pengembangan Instrumen Penelitian Pendidikan. Yogyakarta: Graha IImu

Supartono. (2018). Analisis Hasil Belajar dan Minat Wirausaha Siswa Menggunakan Bahan Ajar Berorientasi Chemoentrepreneurship. Jurnal Inovasi Pendidikan, Vol 12, No. 1, 2018, halaman $2065-2074$.

Taufiq, Agus dkk. 2010. Pendidikan Anak di SD. Jakarta: Universitas Terbuka

Widyanti, I. (2017). Kecenderungan Kualitas Rasa Percaya Diri Siswa Kelas V SD Negeri 2 Sukadana Kabupaten buleleng. E-Journal PGSD Universitas Pendidikan Ganesha Mimbar PGSD Vol: 5 No: 2 Tahun: 2017 